\title{
Organic mercurial encephalopathy
}

\author{
W. J. HAY, A. G. RICKARDS, W. H. MCMENEMEY, \\ AND J. N. CUMINGS
}

\begin{abstract}
From the Royal Infirmary, Lancaster, and the National Hospitals for Nervous
Diseases and the Institute of Neurology, Queen Square and Maida Vale, London
\end{abstract}

Poisoning with organic mercury is uncommon (Cumings, 1959) and there have been few detailed pathological studies (Hunter and Russell, 1954; Brown, 1954). With the increasing use of insecticides and fungicides containing organic mercury more cases may be encountered. There has also been described from Japan another type of organic mercurial poisoning (Kurland, Faro, and Siedler, 1960); the occurrence of mercurial poisoning in Iraq has also been described (Jalili and Abbasi, 1961). This paper details a case occurring in England.

\section{CASE HISTORY}

The patient, a man aged 29 years, was first seen by one of us (W.J.H.) on 19 June 1960. During the previous week he had noticed difficulty in speaking and increasing weakness of the legs, with a tendency to stagger as though drunk. For two days his vision had been blurred. There had been slight loss of weight but his health in other respects had been good and there was no previous illness of note. There was no family history of neurological disorder. He smoked and drank only in moderation. He volunteered the information that he was employed in a factory manufacturing insecticides, where he was concerned specifically with the preparation of ethyl mercury chloride.

He was a small thin man of $118 \mathrm{lb}$. $(53 \mathrm{~kg}$.). His breath was foul; there was some gingivitis but no pigmentation of the mucous membranes. His blood pressure was $140 / 80 \mathrm{~mm}$. $\mathrm{Hg}$; no abnormality was detected in the heart, lungs, or abdomen, the only significant findings being in the nervous system. The optic discs were pale. Although at this time ocular movement was not definitely impaired, he seemed to experience some difficulty in following the examiner's finger with his eyes. No limitation of the visual fields was detected on confrontation. There was marked ataxic dysarthria and bilateral nerve deafness. His response to questioning was slow; the deafness and dysarthria made it difficult to assess his mental capacity but it appeared to be considerably impaired. There was gross incoordination and dysdiadochokinesia of both arms with slight weakness and increased tendon reflexes. The abdominal reflexes were normal. There was also marked weakness of both legs with incoordination of the heel-to-knee test and very marked cerebellar ataxia on walking. The tendon reflexes were increased but the plantar responses were flexor. There was no sensory change. The cerebrospinal fluid was normal apart from a protein level of $50 \mathrm{mg}$. per $100 \mathrm{ml}$; the blood count and the blood sugar were normal and the Wassermann reaction negative. The urine contained a little albumin and a few red blood cells and granular casts. The level of urinary mercury was $400 \mu \mathrm{g}$. per 24 hours falling to $210 \mu \mathrm{g}$. on the fifth and $150 \mu \mathrm{g}$. on the sixteenth day. Both B.A.L. and calcium versenate were used therapeutically in view of the diagnosis of organic mercurial encephalopathy but the patient steadily deteriorated, first with myoclonic contractions and later with stupor and infections of the lungs and kidneys. He died on 15 October 1960, 18 weeks after symptoms first developed and 25 weeks after his first exposure to mercury.

\section{PATHOLOGICAL FINDINGS}

NECROPSY Post-mortem examination was carried out eight hours after death. The body was that of a grossly emaciated young male with severe flexion deformities of the lower limbs and extensive bed sores on the buttocks, heels, and sacrum. Examination of thoracic and abdominal organs revealed no significant abnormality, and histological examination of the lungs, aorta, adrenal, thyroid and pituitary glands, stomach, liver, spleen, heart, and kidneys showed no significant abnormalities. Naked-eye inspection of the brain showed neither evidence of raised intracranial pressure nor obvious signs of focal or general atrophy. On cutting the brain the ventricles were not dilated, and there was no macroscopic evidence of demyelination. Apart from occasional filmy adhesions in the subarachnoid space the spinal cord showed no naked-eye lesions. The brain was fixed in formol ammonium bromide and the spinal cord in $10 \%$ formaldehyde.

HISTOLOGY Sections of the brain from various areas show a fine cribriform appearance of the white matter. This porosity affected the corpus callosum (Fig. 1), the anterior commissure, and the subcortical white matter (Fig. 2) in the temporal and occipital regions. These areas consisted of aggregates of small roundish 


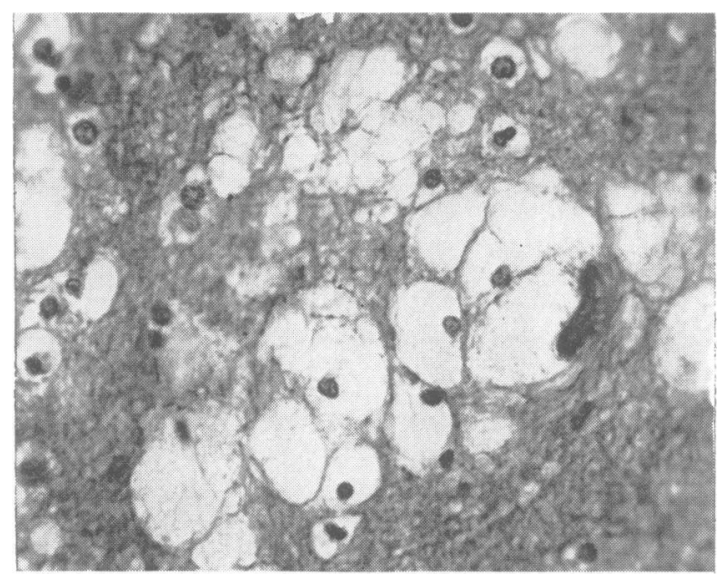

FIG. 1. Corpus callosum. Spaces, arranged in clusters, with the nuclei of oligodendrocytes within them. The spaces are unstained but sometimes finely reticulated. Paraffin. Haematoxylin and eosin $\times 360$.

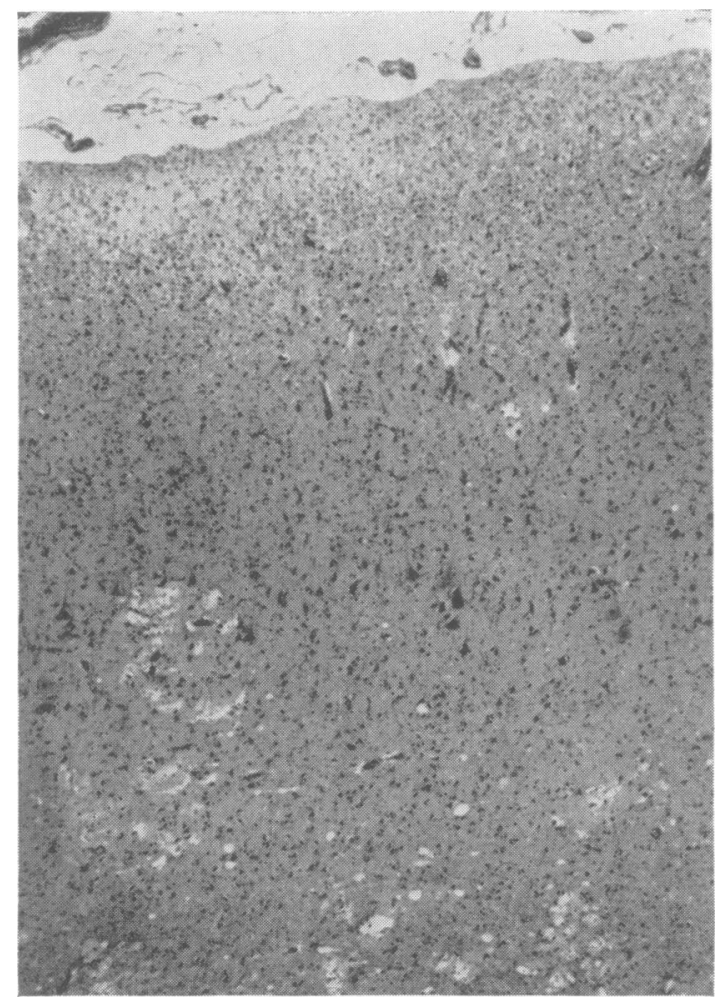

FIG. 2. Left motor cortex. Clusters of spaces in the white matter and in the deepest layers of the cortex similar to those seen elsewhere. There is loss of cells especially in laminae II and III, while those in lamina $V$ are pyknotic. Celloidin. Nissl $\times 70$. spaces in which nuclei could be identified, and these were oligodendrocytes. Demyelination was not evident even though there was some swelling and beading of the fibres in the areas of these cells. Axons were reduced in numbers and many were thickened, some with bulbous swellings. Free fat was not present but there was a slight degree of reactive activity affecting histiocytes and astrocytes.

The cerebral cortex was affected in relation to the cribriform areas; especially in the calcarine cortex was there loss of nerve cells in all layers but especially in lamina V. Also involved but to a lesser degree were the motor and sensory cortex, the caudal part of the first temporal gyrus, and the parastriatic region.

Although other areas were affected changes were less marked, while the striatum, globus pallidus, thalamus, optic tracts, and chiasma and periaqueductal grey matter were all normal.

The cerebellum showed small areas of porosity in the white matter but the main change affected some of the Purkinje cells (Fig. 3) which were degenerative or absent with many empty 'baskets'. In a few places the granule cells were reduced in numbers. Other parts of the cerebellum were normal.

The brain-stem was almost normal, but there was $\vec{\theta}$ some pallor of the myelin in the lateral and anteriop $\bullet$ corticospinal tracts in the spinal cord in all regions

Vascular changes were present to some extent in the brain and very slightly in the spinal cord. These consisted of some collagenous thickening of the arterioles but more especially in a fine adventitia. $\vec{\varphi}$ stippling of the capillary walls, best seen in th: dentate nucleus.

CHEMICAL ANALYSIS Parts of the brain, liver, and kidney were analysed for mercury and the results are compared with those in other reported cases in Table I. This case differs from some others in that the greatest amount of mercury is found in the corpus callosum and least in the cerebellum. As in other cases large quantities are found in the kidney with less in the liver.

As will be seen a wide variation may occur between different organs and within different parts of the central nervous system. In three of the cases of Minamata disease reported by Kurland et al. (1960) of 26 days', 90 days', and 553 days' duration the mercury concentration in the brain was found to be $1,500,500$, and $500 \mu \mathrm{g} . / 100 \mathrm{~g}$. tissue respectively. In $ᄋ$ their control case of a Minamata patient dying from an unrelated disease the mercury concentration in the brain was $10 \mu \mathrm{g}$. $/ 100 \mathrm{~g}$. Five cats dying of Minamata disease had concentrations of $1,800,800$, $1,900,1,000$, and $900 \mu \mathrm{g} . / 100 \mathrm{~g}$. in the brain whereas three control cats all had concentrations of $10 \mu \mathrm{g}$./ 100 g. mercury. , 


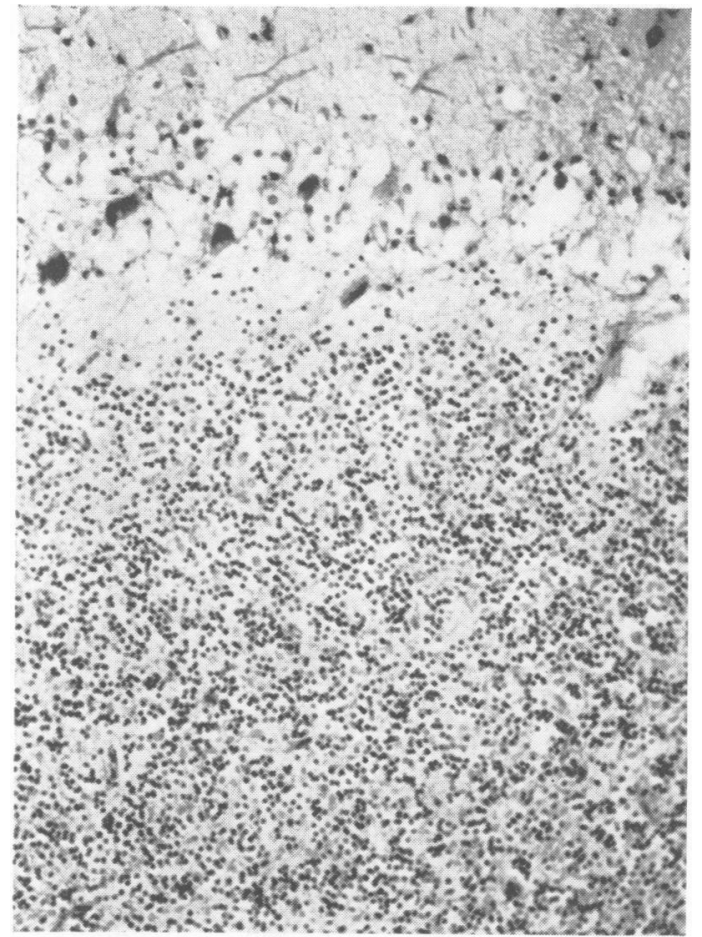

FIG. $3 \mathrm{a}$

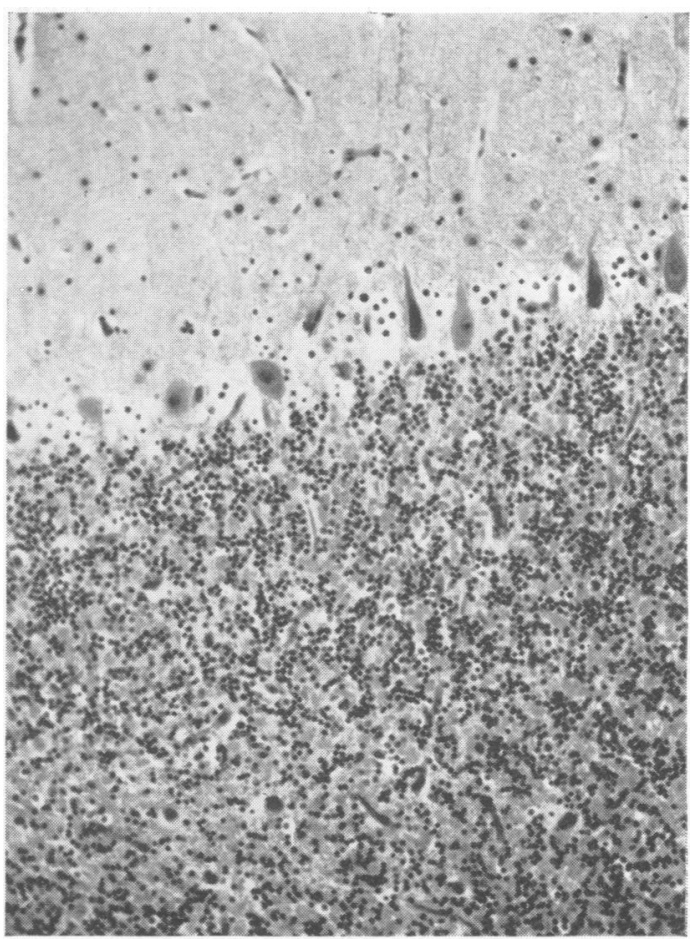

FIG. 3b

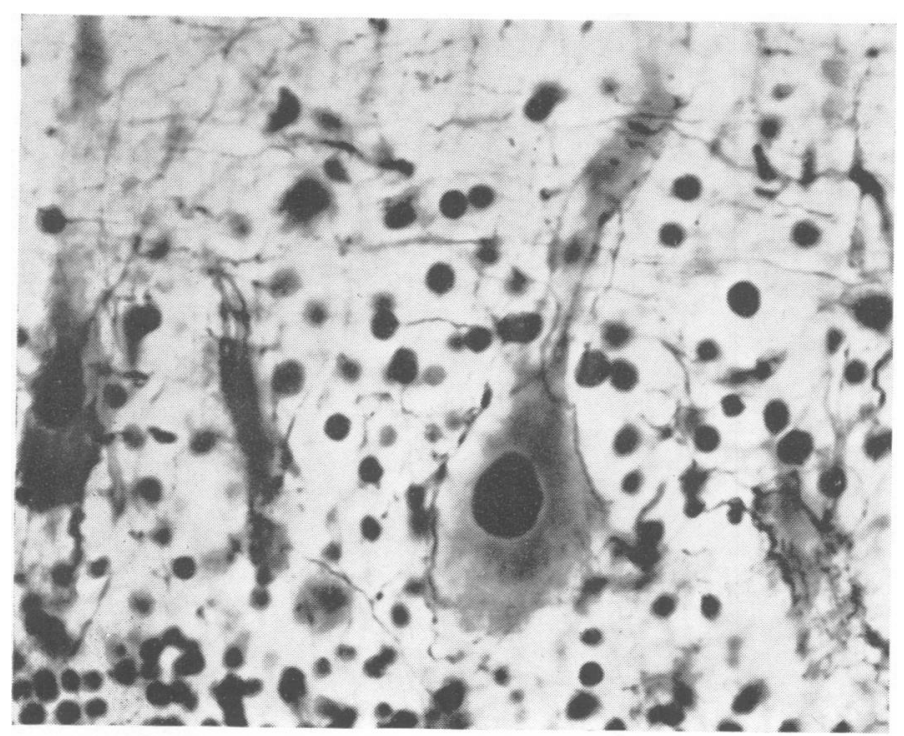

FIG. 3c
FIG. 3. Cerebellum.

a Spongiform degeneration of Purkinje cell layer with advanced changes in all of the visible cells. There is some paucity of granule cells, but nowhere is it very marked. Paraffin.

Haematoxylin and eosin $\times 110$.

b Early degeneration of Purkinje cells with lack of response on the part of the Bergmann cells. Two of the Purkinje cells are strikingly pyknotic and concentrated. Paraffin. Luxol fast blue $\times 110$ c Degeneration of Purkinje cells with empty 'baskets'. Celloidin. Davenport $\times 595$. 
TABLE I

TISSUE MERCURY CONCENTRATIONS IN THIS AND OTHER REPORTED CASES ${ }^{1}$

\begin{tabular}{|c|c|c|c|c|}
\hline Series & Liver & Kidney & Spinal Cord & Brain \\
\hline Ahlmark (1948) & $\begin{array}{l}1,960 \\
1,410\end{array}$ & $\begin{array}{r}3,040 \\
300\end{array}$ & 380 & $\begin{array}{l}450-510 \\
400-970\end{array}$ \\
\hline Lundgren and Swensson (1949) & 1,410 & 304 & $\begin{array}{r}390 \\
340-970\end{array}$ & $\begin{array}{l}500 \text { (centrum ovale) } \\
410 \text { (frontal cortex) } \\
490 \text { (corpus callosum) } \\
340 \text { (pons) } \\
510 \text { (cerebellum) } \\
970 \text { (basal ganglia) }\end{array}$ \\
\hline Höök et al. (1954) & 3,900 & 2,700 & 400 & 1,200 \\
\hline Ashbel' and Tret'iakova (1958) & 3,575 & 3,360 & 50 & 2,820 \\
\hline Kurland et al. (1960) & 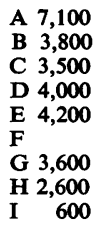 & $\begin{array}{r}14,400 \\
4,800 \\
9,900 \\
4,100 \\
10,600 \\
\\
2,900 \\
3,700 \\
1,300\end{array}$ & & $\begin{array}{r}1,000 \\
1,500 \\
800 \\
900 \\
2,100 \\
1,000 \\
500 \\
500 \\
100\end{array}$ \\
\hline Present case & 1,680 & 8,160 & & $\begin{array}{l}6,150 \text { (corpus callosum) } \\
97 \text { (cerebellum) } \\
720 \text { (white matter) } \\
693 \text { (cortex) }\end{array}$ \\
\hline
\end{tabular}

\section{DISCUSSION}

The clinical effects of poisoning by alkyl mercury compounds is fairly constant as has been shown by Swensson (1952) and by Hunter, Bomford, and Russell (1940). Similarly Minamata disease presented a like picture (McAlpine and Araki, 1959; Kurland et al., 1960). The clinical picture of the case described here differed little from those already recorded; however, the early onset of ataxia suggested that the cerebellum was involved even though as found later the mercury content was not greatly raised as compared with that of the corpus callosum.

Constriction of the visual fields was a constant feature of the patients described by Hunter et al. (1940) and was frequently seen in the Minamata cases. The neuronal atrophy of the calcarine cortex in our case was of such severity that constriction of the visual fields or even blindness would be expected had it been possible to make an adequate examination at a later stage, when the patient was stuporose.

The marked degree of porosity in the corpus callosum, together with the high mercury content of that region, suggests a direct toxic action on the oligodendrocytes rather than on other cells such as astrocytes. The appearances of these were not considered to be similar to the 'grape-like bodies of Buscaino' which have been regarded as artefacts (Ferraro, 1928; Weil, 1946).

That certain areas, such as the calcarine cortex, the cerebellum, and the corpus callosum, are involved in organic mercurial poisoning would appear to be due to a high concentration of the toxic substance in these regions.

\section{SUMMARY}

Clinical, pathological, and chemical aspects of a case of fatal organic mercurial encephalopathy ares described. The main neuropathological change wasi selective cortical damage, especially of the calcarine, parastriate, motor, and sensory areas, and of the caudal part of the first temporal gyrus. The loss of neurones was associated with marked porosity of the underlying white matter and swelling of the oligodendrocytes. The chemical analysis showed an especially high level of mercury in the corpus callosum.

For their assistance we are indebted to J. H. Jellyman, Esq., H.M. Coroner for Lancaster, to Dr. Neil Gordon, to Miss M. Doe and Mr. R. Shortman, and to Mr. G. Cox.

\section{REFERENCES}

Ahlmark, A. (1948). Brit. J. industr. Med., 5, 117.

Ashbel', S. I., and Tret'iakova, V. A. (1958). Pharmacol. Toxicol., 21, 185.

Brown, I. A. (1954). A.M.A. Arch. Neurol. Psychiat., 72, 674.

Cumings, J. N. (1959). Heavy Metals and the Brain. Blackwell, Oxford.

Ferraro, A. (1928). Arch. Neurol. Psychiat. (Chicago), 20, 1065.

Höök, O., Lundgren, K.-D., and Swensson, A. (1954). Acta med. scand., 150, 131.

Hunter, D., and Russell, D. S. (1954). J. Neurol. Psychiat., 17, 235. Bomford, R. R., and Russell, D. S. (1940). Quart. J. Med., N.S. 9, 193.

Jalili, M. A., and Abbasi, A. H. (1961). Personal communication.

Kurland, L. T., Faro, S. N., and Siedler, H. (1960). Wld. Neurol., $1,370$.

Lundgren, K.-D., and Swensson, A. (1949). J. industr. Hyg., 31, 190

McAlpine, D., and Araki, S. (1959). A.M.A. Arch. Neurol., 1, 522.

Swensson, A. (1952). Acta med. scand., 143, 365.

Weil, A. (1946). Textbook of Neuropathology, 2nd ed., p. 6. Heinemann, London. 